Article

\title{
Extensive Degradation and Low Bioavailability of Orally Consumed Corn miRNAs in Mice
}

\author{
Haiqiu Huang ${ }^{1,2}$ (D), Cindy D. Davis ${ }^{2}$ and Thomas T. Y. Wang ${ }^{1, *}$ \\ 1 Diet, Genomics and Immunology Laboratory, Beltsville Human Nutrition Research Center, USDA-ARS, \\ Beltsville, MD 20705, USA; tennisqiu@gmail.com \\ 2 Office of Dietary Supplements, National Institutes of Health, Bethesda, MD 20892, USA; \\ davisci@mail.nih.gov \\ * Correspondence: Tom.Wang@ars.usda.gov; Tel.: +1-(301)-504-8459
}

Received: 23 January 2018; Accepted: 12 February 2018; Published: 15 February 2018

\begin{abstract}
The current study seeks to resolve the discrepancy in the literature regarding the cross-kingdom transfer of plant microRNAs (miRNAs) into mammals using an improved miRNA processing and detection method. Two studies utilizing C57BL/6 mice were performed. In the first study, mice were fed an AIN-93M diet and gavaged with water, random deoxynucleotide triphosphates (dNTP) or isolated corn miRNAs for two weeks ( $n=10$ per group). In the second study, mice were fed an AIN-93M diet, or the diet supplemented with $3 \%$ fresh or autoclaved corn powder for two weeks ( $n=10$ per group). Corn miRNA levels were analyzed in blood and tissue samples by real-time PCR (RT-PCR) following periodate oxidation and $\beta$ elimination treatments to eliminate artifacts. After removing false positive detections, there were no differences in corn miRNA levels between control and treated groups in cecal, fecal, liver and blood samples. Using an in vitro digestion system, corn miRNAs in AIN-93M diet or in the extracts were found to be extensively degraded. Less than $1 \%$ was recovered in the gastrointestinal tract after oral and gastric phases. In conclusion, no evidence of increased levels of corn miRNAs in whole blood or tissues after supplementation of corn miRNAs in the diet was observed in a mouse model.
\end{abstract}

Keywords: corn; cross-kingdom transfer; C57BL/ 6 mouse; miRNA; periodate oxidation

\section{Introduction}

MicroRNA (miRNA) are a group of small, functional, non-protein coding RNA oligonucleotides that were discovered two decades ago and are universally found in microorganisms, plants, and animals $[1,2]$. The miRNAs have been shown to mediate $30 \%$ of the post-transcriptional silencing in mammals and modulate a wide range of critical biological processes, including neuronal development, cell differentiation, apoptosis, proliferation, and immune response [1-5]. In 2012, Zhang and colleagues reported a novel cross-kingdom uptake of intact rice miRNAs (miR156a and miR168a) via dietary consumption into circulation and organs of humans and mice [6]. More importantly, the rice miR168a was reported to directly down-regulate the expression of a cholesterol regulation-related gene LDLRAP1 in the liver [6]. This result suggests ingestion of plant miRNA may influence physiology and health in humans. The importance of this finding was signified by the number and breadth of follow-up studies [7-18]. However, various follow up bioinformatic studies, in vitro and in vivo studies to identify the cross-kingdom transfer of plant miRNAs and the presence of exogenous miRNAs in human or mammalian circulation or organs lead to mixed results [7-18]. At present, no definitive conclusion has been reached regarding the extent and prevalence of dietary plant miRNAs entering circulation.

The detection of plant miRNAs in human or animal samples can be challenging and confounded by the potential artifacts introduced in the sample preparation, sequence detection, and difficulties in 
delineating the origin of miRNAs $[15,16]$. These inherent problems related to plant miRNA analysis may contribute in part to the difficulty in validating/confirming cross-kingdom regulation by plant miRNAs. A good marker for the plant origin of miRNAs for specific detection of plant miRNAs in biological samples is the distinct methylation patterns on the $3^{\prime}$ ends of plant and mammalian miRNAs [19]. Taking advantage of $3^{\prime}$ protective property of plant miRNA, we previously reported that periodate oxidation and $\beta$ elimination reaction treatment specifically targets the unmethylated $3^{\prime}$ end of miRNAs to eliminate the artifacts in PCR detection of plant miRNAs in biological samples [20]. Hence, we believe that analysis using this method may help us validate the presence of plant miRNA in biological samples and elucidate bioavailability of plant miRNA in vivo.

The present study seeks to test the hypothesis that dietary plant-derived miRNA can survive the gastrointestinal (GI) tract and be taken up into circulation and tissues in vivo. This study utilized corn as the source of dietary plant miRNAs. Common plant miRNAs, such as miR156a, miR164a, and miR167a, are detected at high levels in corn [21]. More importantly, corn and its processed products are the most widely used/consumed ingredients in foods [22,23], therefore the cross-kingdom transfer of these miRNAs could bear significant biological, health and economic impacts. Corn or corn miRNA extract were incorporated into rodent diet. An autoclaving-base method was developed to degrade corn miRNAs to be use as a control treatment to eliminate the matrix effect as a variable. Corn miRNAs in the gastrointestinal tract, liver, and blood from animals fed a corn supplemented diet or gavaged with miRNA extracts from corn were determined using the periodate oxidation/ $\beta$-elimination method. Our results indicate that corn miRNA was extensively degraded in the GI tract and that the uptake into circulation and tissues was minimal.

\section{Materials and Methods}

\subsection{Reagents and Chemicals}

Tris hydrochloride ( $\mathrm{pH}$ 9.0), sodium dodecyl sulfate (SDS), lithium chloride (LiCl), ethylenediaminetetraacetic acid (EDTA), phenol ( $\mathrm{pH} 8.0)$, chloroform-isoamyl alcohol $(24: 1 ; v / v)$, phenol-chloroform-isoamyl alcohol (25:24:1; v/v/v), sodium acetate ( $\mathrm{M}, \mathrm{pH}$ 5.2), sodium chloride $(\mathrm{NaCl})$, polyethylene glycol 8000, and pepsin were obtained from Sigma-Aldrich (St. Louis, MO, USA). RNA oligos with $3^{\prime}$ end $2^{\prime}-O-$ methylation were synthesized by Integrated DNA Technologies, Inc. (Coralville, IA, USA).

Corn small RNA isolation. Fresh corn used in this study was purchased from a local market (Beltsville, MD, USA). Corn small RNAs were isolated according to a previously published protocol [24]. Briefly, $0.1 \mathrm{~g}$ of pulverized plant sample was added in a $1.5 \mathrm{~mL}$ microcentrifuge tube with $500 \mu \mathrm{L}$ of $\mathrm{LiCl}$ extraction buffer and $500 \mu \mathrm{L}$ of phenol $\mathrm{pH}$ 8.0. Extraction mixture was vortexed for $1 \mathrm{~min}$ and incubated for $5 \mathrm{~min}$ at $60^{\circ} \mathrm{C}$. Then the mixture was centrifuged at $20,000 \times \mathrm{g}$ at $4{ }^{\circ} \mathrm{C}$ for $10 \mathrm{~min}$. The upper phase was transferred to a new microcentrifuge tube and $600 \mu \mathrm{L}$ of chloroform-isoamyl alcohol $(24: 1 ; v / v)$ was added. The mixture was vortexed and centrifuged, and the upper phase was transferred to a new microcentrifuge tube and incubated at $65^{\circ} \mathrm{C}$ for $15 \mathrm{~min}$. Then, $50 \mu \mathrm{L}$ of $5 \mathrm{M}$ $\mathrm{NaCl}$ and $63 \mu \mathrm{L}$ of $40 \%$ polyethylene glycol $8000(w / v)$ was added followed by incubation on ice for at least $30 \mathrm{~min}$. The low molecular weight RNA was separated from the pellet which consisted of high molecular weight RNA and DNA by centrifugation. The supernatant was mixed with $500 \mu \mathrm{L}$ of phenol-chloroform-isoamyl alcohol (25:24:1; $v / v / v)$. The mixture was centrifuged, and the supernatant was transferred to a new microcentrifuge tube with $50 \mu \mathrm{L}$ of $3 \mathrm{M}$ sodium acetate $\mathrm{pH} 5.2$ and $1200 \mu \mathrm{L}$ of absolute ethanol. RNA samples were incubated at $-20^{\circ} \mathrm{C}$ overnight. The small RNA was precipitated, washed twice, and dried. Isolated RNA was resuspended in RNase-free water and kept in $-80^{\circ} \mathrm{C}$. RNA concentration and purity were determined using Nanodrop 8000 Spectrophotometer (Thermo Fisher Scientific, St. Louis, MO, USA). 


\subsection{Animals, Diets, and Study Design}

Male C57BL/6 mice (5-week old, Charles River, Wilmington, MA, USA) were acclimated for 1 week and given free access to water and AIN-93M diet (D10012M, Research Diet, Inc., New Brunswick, NJ, USA). Then the animals were randomly assigned to two subsequent studies (30 animals each). For study 1, all animals were fed a control diet (AIN-93M, 10\% calorie from fat). The animals were divided into three treatments $(n=10 /$ treatment) (1) control group (water); (2) random nucleotides (25 $\mu \mathrm{g}$ in $100 \mu \mathrm{L}$ distilled water) (dNTP group); (3) purified small RNA isolated from corn kernel ( $25 \mu \mathrm{g}$ in $100 \mu \mathrm{L}$ distilled water) (Corn sRNA group). Random nucleotides and corn small RNA were administered by gavage using water as a vehicle and the control group was given $100 \mu \mathrm{L}$ water. For study 2, the animals were assigned to the following three groups: (1) control diet (AIN-93M, 10\% calorie from fat) (Control group); (2) AIN-93M $+3 \%$ autoclaved corn kernel powder (Autoclaved corn group); (3) AIN-93M $+3 \%$ fresh corn kernel powder (Fresh corn group) (Supplementary Materials Table S1). Corn kernel was incorporated into diets as a ground powder. The amounts of corn small RNA or corn kernel were calculated based on 1 serving/day of $166 \mathrm{~g}$ corn kernel for human consumption (National Nutrient Database for Standard Reference, Release 28, Agricultural Research Service-USDA) and a $5 \mathrm{~g}$ per day of food intake for the mouse. The powder was blended into the formulated diet by Research Diets, Inc. (New Brunswick, NJ, USA). Animals were single-housed in ventilated racks for the duration of the experiment. Fecal samples were collected daily. At the end of the two-week feeding period, blood was collected by cardiac puncture with syringes previously rinsed with potassium EDTA solution $(15 \% w / v)$ and kept on ice. Contents of cecum and colon, and liver samples were collected, immediately frozen in liquid nitrogen. All samples were kept at $-80^{\circ} \mathrm{C}$ before analysis. This study was carried out in strict accordance with the recommendations in the Guide for the Care and Use of Laboratory Animals of the National Institutes of Health. The protocol was approved by the U.S. Department of Agriculture (USDA) Agricultural Research Service (ARS) Beltsville Area Institutional Animal Care and Use Committee (IACUC) (Protocol \# 16-017).

\subsection{Plant miRNA Isolation and Detection}

MiRNA isolation from the blood and tissue samples was performed using the mirVana ${ }^{\mathrm{TM}}$ miRNA Isolation Kit (with phenol) from Thermo Fisher Scientific (St. Louis, MO, USA) according to the manufacturer's protocol. Plant miRNA was detected and quantitated using quantitative real-time PCR (qRT-PCR) as previously described [20]. Specific plant miRNA primers were purchased from Thermo Fisher Scientific (St. Louis, MO, USA) (TaqMan MicroRNA Assay: 000333, 000344, 000348, 241641_mat) and used for microRNA reverse transcription and detection. TaqMan MicroRNA Reverse Transcription Kit (Thermo Fisher Scientific, St. Louis, MO, USA) and the small RNA-specific RT primer from the TaqMan MicroRNA Assays were used to reverse transcribe complementary DNA. Five $\mu \mathrm{L}$ of $2 \mathrm{ng} / \mu \mathrm{L}$ RNA was used in reverse transcription and $1 \mu \mathrm{L}$ of reverse transcription product was used in quantitative PCR. PCR was performed on ViiA7 Real-Time PCR System (Applied Biosystems, Foster City, CA, USA) using TaqMan Universal PCR Master Mix (Cat No.: 4304437) and miRNA-specific TaqMan primer from the TaqMan MicroRNA Assays. The following amplification parameters were used for PCR: $50{ }^{\circ} \mathrm{C}$ for $2 \mathrm{~min}, 95^{\circ} \mathrm{C}$ for $10 \mathrm{~min}$, and 40 cycles of amplification at $95^{\circ} \mathrm{C}$ for $15 \mathrm{~s}$ and $60^{\circ} \mathrm{C}$ for $1 \mathrm{~min}$.

\subsection{In Vitro Digestion of Plant miRNAs}

An in vitro digestion model was used to mimic oral, gastric, and intestinal digestion of plant miRNAs and the procedure was adapted from a previously published protocol [25]. Rodent fecal samples were collected at the moment of excretion and immediately frozen in liquid nitrogen. Fecal pellets were re-suspended in LB broth in an anaerobic condition and vortexed to homogenize and release the fecal bacteria into the supernatant. The fecal suspension was then centrifuged at $800 \times g$ for $3 \mathrm{~min}$ to separate the fecal debris. Fecal bacteria were expanded in LB broth in anaerobic condition 
at $37{ }^{\circ} \mathrm{C}$ and cryopreserved in $25 \%$ glycerol in $-80{ }^{\circ} \mathrm{C}$ before treatment. Briefly, the oral digestion phase: an electrolyte buffer (composed of $\mathrm{KCl}, \mathrm{KH}_{2} \mathrm{PO}_{4}, \mathrm{NaHCO}_{3}, \mathrm{NaCl}, \mathrm{MgCl}{ }_{2}\left(\mathrm{H}_{2} \mathrm{O}\right)_{6},\left(\mathrm{NH}_{4}\right)_{2} \mathrm{CO}_{3}$, $\left.\mathrm{CaCl}_{2}\left(\mathrm{H}_{2} \mathrm{O}\right)_{2}\right)$ and $75 \mathrm{U} / \mathrm{mL} \alpha$-amylase at $\mathrm{pH}$ 7; the gastric digestion phase: an electrolyte buffer and $2000 \mathrm{U} / \mathrm{mL}$ pepsin at $\mathrm{pH} 3$; the intestinal digestion phase: an electrolyte buffer, $100 \mathrm{U} / \mathrm{mL}$ pancreatin, and $10 \mathrm{mM}$ bile at $\mathrm{pH} 7$; the colonic phase: fecal bacteria culture in anaerobic condition (seeded at $1 \times$ $10^{7}$ per $\mathrm{mL}$ ) at $37^{\circ} \mathrm{C}$. Oral phase: $1 \mathrm{~g} / \mathrm{mL}$ of AIN-93M diet with fresh corn, $25 \mu \mathrm{g} / \mathrm{mL}$ of corn miRNA extract, or $25 \mu \mathrm{g} / \mathrm{mL}$ of methylated or unmethylated miR171j were mixed with the oral phase digestion buffer at $1: 1(v / v)$ and incubated at $37^{\circ} \mathrm{C}$ for $2 \mathrm{~min}$. Gastric Phase: the oral mix, after incubation, was mixed with the gastric phase digestion buffer at $1: 1(v / v)$ and incubated at $37^{\circ} \mathrm{C}$ for $2 \mathrm{~h}$. Intestinal phase: the gastric mix, after incubation, was then mixed with the intestinal phase digestion buffer at $1: 1(v / v)$ and incubated at $37^{\circ} \mathrm{C}$ for $2 \mathrm{~h}$. Colonic phase: the intestinal mix, after incubation, was mixed with the colonic phase digestion fluid at $1: 1(v / v)$ and incubated at $37^{\circ} \mathrm{C}$ in anaerobic condition overnight. Digestion samples were collected at each phase and flash frozen in liquid nitrogen and stored at $-80{ }^{\circ} \mathrm{C}$ until analysis. MiRNAs were isolated using the mirVana ${ }^{\mathrm{TM}}$ miRNA Isolation Kit (with phenol) and plant miRNAs were detected using RT-PCR described above. Recovery of miRNAs was calculated as the percentage of miRNAs detected after each digestion phase to the number of miRNAs added at the beginning of the assay.

\subsection{Statistical Analysis}

All experiments were conducted in triplicate and representative data was reported as a mean \pm standard deviation. A $0.005 \mathrm{amol}$ to $500 \mathrm{fmol}$ range of synthetic miRNAs were used to construct a standard curve in qRT-PCR. Linear regression and statistical analysis were performed using GraphPad Prism 6 (2015, GraphPad Software, La Jolla, CA, USA). Significance differences between means from treated groups compared to controls were determined using one-way analysis of variance (ANOVA) and Tukey's Honestly Significant Difference (HSD) test. Statistical significance was defined at $p \leq 0.05$.

\section{Results}

\subsection{Food Intake, Body Weight and Levels of Corn miRNAs Consumption}

Two animal studies were conducted to test our hypothesis. In study 1 , animals received daily gavage of (1) $100 \mu \mathrm{L}$ ultrapure water, (2) $100 \mu \mathrm{L}$ of $250 \mathrm{ng} / \mu \mathrm{L}$ of random dNTP, and (3) $100 \mu \mathrm{L}$ of $250 \mathrm{ng} / \mu \mathrm{L}$ of corn sRNA isolates. The isolates were pre-determined to contain $56.03 \mathrm{pg}$ of miR156a, $13.2 \mathrm{pg}$ of miR164a, and $1215.63 \mathrm{pg}$ of miR167a per $25 \mu \mathrm{g}$ of corn sRNA isolates. In study 2, animals were fed (1) AIN93M base diet, (2) AIN93M + 3\% fresh corn powder, (3) AIN93M + 3\% autoclaved corn powder. The diet supplemented with the fresh corn powder was determined to contain $173 \mathrm{pg}$ of miR156a, $65 \mathrm{pg}$ of miR164a, and $515 \mathrm{pg}$ of miR167a per gram diet. No significant reduction of corn miRNA in the diet was detected between the start and end of the study (Supplementary Materials, Figure S1). Autoclaving corn powder at $121^{\circ} \mathrm{C}$ for 30 min degraded $99 \%, 98 \%$, and $97 \%$ of miR 156 , miR164a, and miR167a, respectively (Supplementary Materials, Figure S2). The autoclaved corn powder was used as matrix control. For the corn sRNA extract study, no difference was observed in body weight and food intake throughout the two-week feeding period (Figure 1A,B). For corn powder supplementation study, no difference was observed in final body weight and food intake. Interestingly, total body weight gain over the 2-week feeding period was significantly lower in the fresh-corn fed animals $(1.03 \pm 0.89 \mathrm{~g})$, comparing to that of autoclaved-corn fed animals $(2.03 \pm 0.68 \mathrm{~g})(p<0.05)$ (Figure 1C,D). 

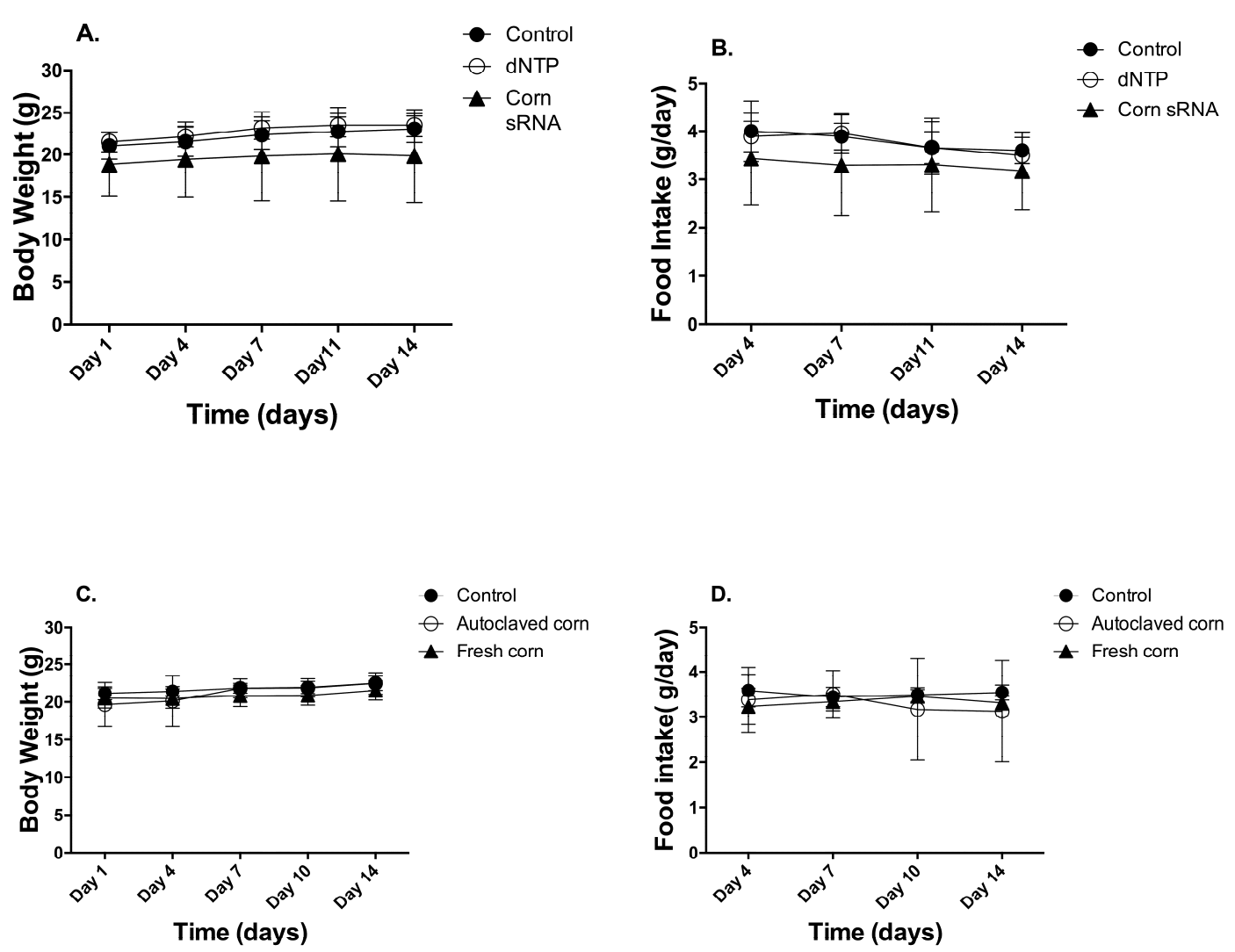

Figure 1. Animal body weight and food intake. Animal body weight and food intake were recorded twice a week and data were presented as Mean \pm Standard Deviation $(n=10,(\mathbf{A}, \mathbf{B})$ for 1 st study and (C,D) for 2nd study).

\subsection{Analysis of Corn miRNAs in Blood and Liver}

Liver and whole blood samples from both studies were analyzed for plant miRNAs (miR156a, miR164a, and miR167a) as determined by the Ct values for specific miRNA from RT-PCR where higher $\mathrm{Ct}$ values indicate lower expression values. In study 1 , using corn small RNA extracts, we found no differences in miRNA $\mathrm{Ct}$ values between the control, dNTP, and corn miRNA groups in the liver and whole blood samples (Figure 2A, upper panel). In the whole blood samples, the Ct values of the three experimental groups was the same as no-template control (Figure 2A, upper panel). By contrast, the $\mathrm{Ct}$ values of the liver samples were significantly lower than the no-template controls (Figure 2A upper panel). However, after periodate oxidation followed by $\beta$ elimination, no differences were detected between the no-template control group and the experimental groups in the liver and blood samples (Figure 2A lower panel, Table 1).

Similar observations were made in the liver and whole blood samples from the 2nd study using the fresh corn powder. No differences were detected in miRNA Ct values among the control, autoclaved corn, and fresh corn groups in the liver and whole blood samples (Figure 2B upper panel). No differences in $\mathrm{Ct}$ values were observed between the no-template control group and the three experimental groups in whole blood samples (Figure 2B). Also, after periodate oxidation followed by $\beta$ elimination, no differences were detected between the no-template control group and the experimental groups in the liver and blood samples (Figure 2B, Table 2). 

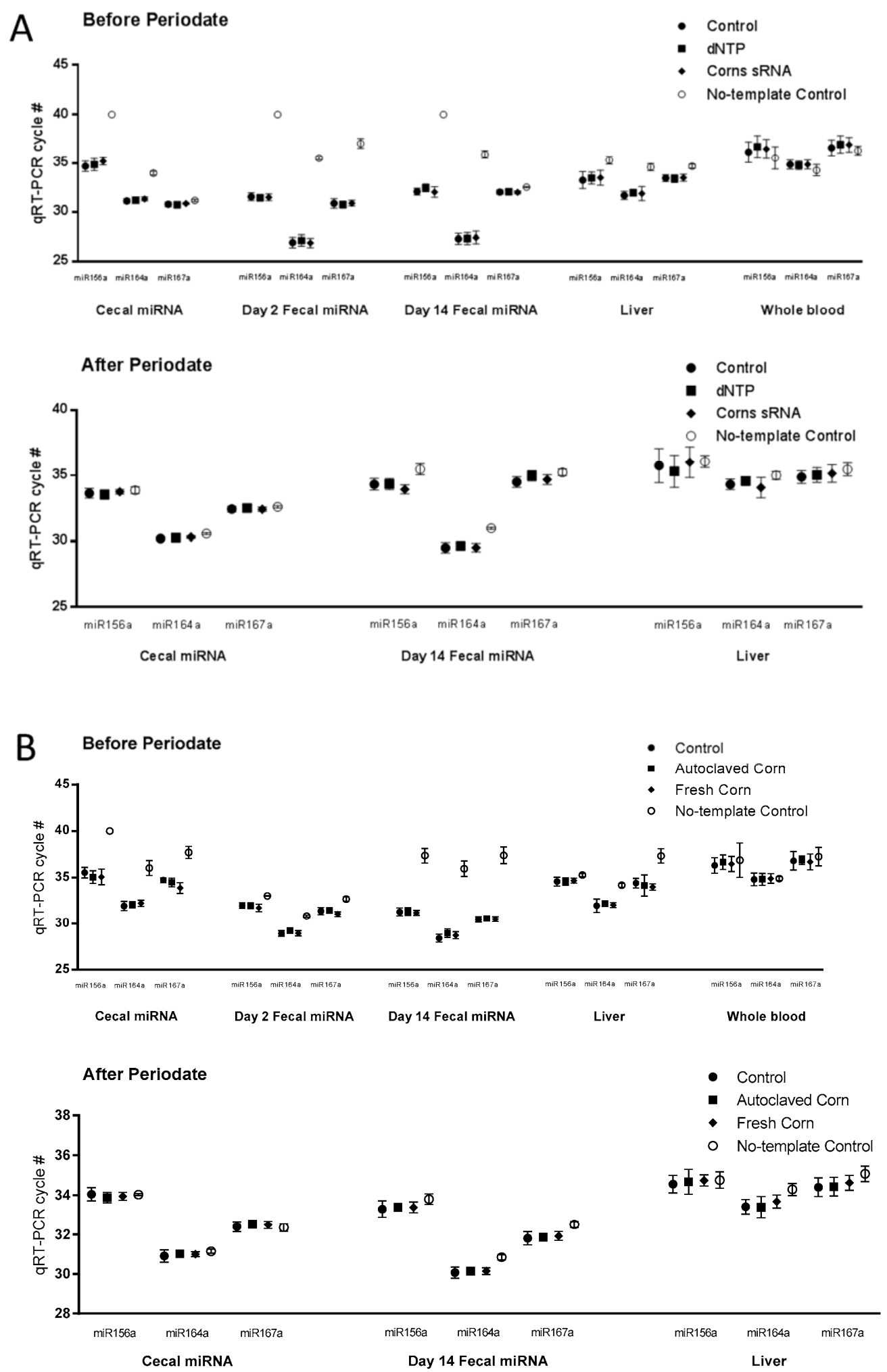

Figure 2. Plant miRNA detection in tissue samples. Plant microRNA (miRNA) were detected and quantified using qRT-PCR as described in Materials and Methods. Cycle numbers of real-time PCR (RT-PCR) before and after periodate oxidation treatment followed by $\beta$ elimination were presented as Mean \pm Standard Deviation ( $n=10$, (A) for 1st study and (B) for 2nd study). 
Table 1. Study 1 miRNA RT-PCR Ct value and calculated concentration after periodate treatment.

\begin{tabular}{|c|c|c|c|c|c|c|c|c|c|c|c|c|}
\hline \multicolumn{13}{|c|}{ Cecal Sample } \\
\hline & \multicolumn{3}{|c|}{ Control } & \multicolumn{3}{|c|}{ dNTP ** } & \multicolumn{3}{|c|}{ Corn miRNA } & \multicolumn{3}{|c|}{ No-Template Control } \\
\hline & \multicolumn{2}{|c|}{ Cycle \# } & \multirow{2}{*}{$\begin{array}{c}\text { Calculated } \\
\text { conc. }(\mathrm{fM}) \text { * } \\
0.873\end{array}$} & \multicolumn{2}{|c|}{ Cycle\# } & \multirow{2}{*}{$\begin{array}{c}\text { Calculated } \\
\text { conc. (fM) } \\
0.936\end{array}$} & \multicolumn{2}{|c|}{ Cycle \# } & \multirow{2}{*}{$\begin{array}{c}\begin{array}{c}\text { Calculated } \\
\text { conc. (fM) }\end{array} \\
0.809\end{array}$} & \multicolumn{2}{|c|}{ Cycle \# } & $\begin{array}{l}\text { Calculated } \\
\text { conc. (fM) }\end{array}$ \\
\hline miR156a & $33.64 \pm 0.37$ & $\mathrm{a}$ & & $33.54 \pm 0.40$ & a & & $33.75 \pm 0.17$ & a & & $33.87 \pm 0.26$ & $\mathrm{a}$ & 0.744 \\
\hline miR164a & $30.20 \pm 0.10$ & c & 9.476 & $30.26 \pm 0.13$ & bc & 9.090 & $30.31 \pm 0.10$ & $\mathrm{~b}$ & 8.780 & $30.56 \pm 0.07$ & a & 7.383 \\
\hline miR167a & $32.43 \pm 0.21$ & a & 2.020 & $32.51 \pm 0.18$ & a & 1.911 & $32.42 \pm 0.17$ & a & 2.034 & $32.60 \pm 0.09$ & a & 1.795 \\
\hline \multicolumn{13}{|c|}{ Day 14 Fecal Sample } \\
\hline & \multicolumn{3}{|c|}{ Control } & \multicolumn{3}{|c|}{ dNTP } & \multicolumn{3}{|c|}{ Corn miRNA } & \multicolumn{3}{|c|}{ No-Template Control } \\
\hline & \multicolumn{2}{|l|}{ Cycle \# } & $\begin{array}{l}\text { Calculated } \\
\text { conc. (fM) }\end{array}$ & \multicolumn{2}{|c|}{ Cycle \# } & $\begin{array}{l}\text { Calculated } \\
\text { conc. (fM) }\end{array}$ & \multicolumn{2}{|c|}{ Cycle \# } & $\begin{array}{l}\text { Calculated } \\
\text { conc. (fM) }\end{array}$ & \multicolumn{2}{|c|}{ Cycle \# } & $\begin{array}{l}\text { Calculated } \\
\text { conc. (fM) }\end{array}$ \\
\hline miR156a & $34.32 \pm 0.45$ & $\mathrm{~b}$ & 0.545 & $34.34 \pm 0.41$ & $\mathrm{~b}$ & 0.537 & $33.94 \pm 0.35$ & $\mathrm{~b}$ & 0.709 & $35.48 \pm 0.42$ & a & 0.244 \\
\hline miR164a & $29.51 \pm 0.40$ & $\mathrm{~b}$ & 15.287 & $29.65 \pm 0.25$ & $\mathrm{~b}$ & 13.873 & $29.52 \pm 0.32$ & $\mathrm{~b}$ & 15.181 & $30.98 \pm 0.08$ & $\mathrm{a}$ & 5.518 \\
\hline miR167a & $34.50 \pm 0.41$ & c & 0.481 & $34.98 \pm 0.39$ & $\mathrm{ab}$ & 0.345 & $34.68 \pm 0.38$ & bc & 0.425 & $35.24 \pm 0.25$ & a & 0.288 \\
\hline \multicolumn{13}{|c|}{ Liver } \\
\hline & \multicolumn{3}{|c|}{ Control } & \multicolumn{3}{|c|}{ dNTP } & \multicolumn{3}{|c|}{ Corn miRNA } & \multicolumn{3}{|c|}{ No-Template Control } \\
\hline & \multicolumn{2}{|c|}{ Cycle \# } & $\begin{array}{l}\text { Calculated } \\
\text { conc. (fM) }\end{array}$ & \multicolumn{2}{|c|}{ Cycle \# } & $\begin{array}{l}\text { Calculated } \\
\text { conc. (fM) }\end{array}$ & \multicolumn{2}{|c|}{ Cycle\# } & $\begin{array}{l}\text { Calculated } \\
\text { conc. (fM) }\end{array}$ & \multicolumn{2}{|c|}{ Cycle \# } & $\begin{array}{l}\text { Calculated } \\
\text { conc. (fM) }\end{array}$ \\
\hline miR156a & $35.76 \pm 1.31$ & $\mathrm{a}$ & 0.201 & $35.32 \pm 1.24$ & $\mathrm{a}$ & 0.272 & $36.02 \pm 1.18$ & $\mathrm{a}$ & 0.168 & $36.08 \pm 0.46$ & $\mathrm{a}$ & 0.161 \\
\hline miR164a & $34.32 \pm 0.40$ & a & 0.545 & $34.58 \pm 0.33$ & a & 0.455 & $34.08 \pm 0.79$ & a & 0.644 & $35.01 \pm 0.30$ & a & 0.338 \\
\hline miR167a & $34.89 \pm 0.49$ & a & 0.367 & $35.03 \pm 0.56$ & a & 0.333 & $35.16 \pm 0.66$ & $\mathrm{a}$ & 0.304 & $35.47 \pm 0.51$ & a & 0.246 \\
\hline \multicolumn{13}{|c|}{ Whole Blood } \\
\hline & & ont & & & NTI & & & $\mathrm{miI}$ & & No-T & ate & trol \\
\hline & Cycle & & $\begin{array}{l}\text { Calculated } \\
\text { conc. (fM) }\end{array}$ & Cycle & & $\begin{array}{l}\text { Calculated } \\
\text { conc. (fM) }\end{array}$ & Cycle & & $\begin{array}{l}\text { Calculated } \\
\text { conc. (fM) }\end{array}$ & $\mathrm{Cyc}$ & & $\begin{array}{l}\text { Calculated } \\
\text { conc. (fM) }\end{array}$ \\
\hline miR156a & $36.17 \pm 1.05$ & $\mathrm{a}$ & 0.151 & $36.72 \pm 1.13$ & $\mathrm{a}$ & 0.103 & $36.50 \pm 0.97$ & $\mathrm{a}$ & 0.120 & $35.58 \pm 1.14$ & $\mathrm{a}$ & 0.228 \\
\hline miR164a & $34.89 \pm 0.47$ & $\mathrm{a}$ & 0.367 & $34.82 \pm 0.43$ & $\mathrm{a}$ & 0.385 & $34.90 \pm 0.47$ & $\mathrm{a}$ & 0.365 & $34.32 \pm 0.57$ & a & 0.545 \\
\hline miR167a & $36.61 \pm 0.80$ & a & 0.111 & $36.96 \pm 0.87$ & $\mathrm{a}$ & 0.087 & $36.93 \pm 0.75$ & $\mathrm{a}$ & 0.089 & $36.33 \pm 0.45$ & $\mathrm{a}$ & 0.135 \\
\hline
\end{tabular}

* The concentrations were calculated with standard curves of respective microRNAs (miRNAs). Cycle numbers of real-time PCR (RT-PCR) were presented as Mean \pm Standard Deviation $(n=10)$. Different letters indicate statistically significant differences $(p \leq 0.05) ;{ }^{* *}$ Random deoxynucleotide triphosphates. 
Table 2. Study 2 miRNA RT-PCR Ct value and calculated concentration after periodate treatment.

\begin{tabular}{|c|c|c|c|c|c|c|c|c|c|c|c|c|}
\hline \multicolumn{13}{|c|}{ Cecal Sample } \\
\hline & \multicolumn{3}{|c|}{ Control } & \multicolumn{3}{|c|}{ dNTP } & \multicolumn{3}{|c|}{ Corn miRNA } & \multicolumn{3}{|c|}{ No-Template Control } \\
\hline & \multicolumn{2}{|l|}{ Cycle \# } & $\begin{array}{l}\text { Calculated } \\
\text { conc. (fM) * }\end{array}$ & \multicolumn{2}{|c|}{ Cycle \# } & \multirow{2}{*}{$\begin{array}{c}\begin{array}{c}\text { Calculated } \\
\text { conc. (fM) }\end{array} \\
0.739\end{array}$} & \multicolumn{2}{|c|}{ Cycle \# } & \multirow{2}{*}{$\begin{array}{c}\begin{array}{c}\text { Calculated } \\
\text { conc. (fM) }\end{array} \\
0.704\end{array}$} & \multicolumn{2}{|c|}{ Cycle \# } & $\begin{array}{l}\text { Calculated } \\
\text { conc. (fM) }\end{array}$ \\
\hline miR156a & $34.05 \pm 0.33$ & $\mathrm{a}$ & 0.873 & $33.88 \pm 0.26$ & $\mathrm{a}$ & & $33.95 \pm 0.20$ & $\mathrm{a}$ & & $34.03 \pm 0.04$ & $\mathrm{a}$ & 0.666 \\
\hline $\operatorname{miR} 164 a$ & $30.92 \pm 0.31$ & $\mathrm{~b}$ & 5.753 & $31.03 \pm 0.08$ & $\mathrm{ab}$ & 5.330 & $31.01 \pm 0.12$ & $\mathrm{ab}$ & 5.405 & $31.15 \pm 0.10$ & $\mathrm{a}$ & 4.905 \\
\hline miR167a & $32.41 \pm 0.26$ & a & 2.048 & $32.54 \pm 0.21$ & a & 1.872 & $32.50 \pm 0.19$ & a & 1.924 & $32.37 \pm 0.20$ & a & 2.106 \\
\hline \multicolumn{13}{|c|}{ Day 14 Fecal Sample } \\
\hline & \multicolumn{3}{|c|}{ Control } & \multicolumn{3}{|c|}{ dNTP } & \multicolumn{3}{|c|}{ Corn miRNA } & \multicolumn{3}{|c|}{ No-Template Control } \\
\hline & \multicolumn{2}{|l|}{ Cycle \# } & $\begin{array}{l}\text { Calculated } \\
\text { conc. (fM) }\end{array}$ & \multicolumn{2}{|l|}{ Cycle \# } & $\begin{array}{l}\text { Calculated } \\
\text { conc. (fM) }\end{array}$ & \multicolumn{2}{|c|}{ Cycle\# } & $\begin{array}{l}\text { Calculated } \\
\text { conc. (fM) }\end{array}$ & \multicolumn{2}{|c|}{ Cycle \# } & $\begin{array}{l}\text { Calculated } \\
\text { conc. (fM) }\end{array}$ \\
\hline miR156a & $33.31 \pm 0.41$ & $\mathrm{~b}$ & 1.098 & $33.40 \pm 0.14$ & $\mathrm{ab}$ & 1.031 & $33.39 \pm 0.27$ & $\mathrm{ab}$ & 1.038 & $33.80 \pm 0.26$ & a & 0.781 \\
\hline miR164a & $30.07 \pm 0.28$ & $\mathrm{~b}$ & 10.369 & $30.15 \pm 0.18$ & $\mathrm{~b}$ & 9.810 & $30.15 \pm 0.17$ & $\mathrm{~b}$ & 9.810 & $30.86 \pm 0.13$ & a & 5.997 \\
\hline miR167a & $31.81 \pm 0.34$ & $\mathrm{~b}$ & 3.104 & $31.87 \pm 0.19$ & $\mathrm{~b}$ & 2.978 & $31.93 \pm 0.23$ & $\mathrm{~b}$ & 2.856 & $32.52 \pm 0.17$ & a & 1.898 \\
\hline \multicolumn{13}{|c|}{ Liver } \\
\hline & \multicolumn{3}{|c|}{ Control } & \multicolumn{3}{|c|}{ dNTP } & \multicolumn{3}{|c|}{ Corn miRNA } & \multicolumn{3}{|c|}{ No-Template Control } \\
\hline & \multicolumn{2}{|l|}{ Cycle \# } & $\begin{array}{l}\text { Calculated } \\
\text { conc. (fM) }\end{array}$ & \multicolumn{2}{|l|}{ Cycle \# } & $\begin{array}{l}\text { Calculated } \\
\text { conc. (fM) }\end{array}$ & \multicolumn{2}{|c|}{ Cycle \# } & $\begin{array}{l}\text { Calculated } \\
\text { conc. (fM) }\end{array}$ & \multicolumn{2}{|c|}{ Cycle \# } & $\begin{array}{l}\text { Calculated } \\
\text { conc. (fM) }\end{array}$ \\
\hline miR156a & $34.55 \pm 0.44$ & $\mathrm{a}$ & 0.465 & $34.67 \pm 0.62$ & $\mathrm{a}$ & 0.428 & $34.75 \pm 0.28$ & $\mathrm{a}$ & 0.405 & $34.76 \pm 0.41$ & $\mathrm{a}$ & 0.402 \\
\hline $\operatorname{miR} 164 a$ & $33.42 \pm 0.36$ & $\mathrm{~b}$ & 1.017 & $33.40 \pm 0.53$ & $\mathrm{~b}$ & 1.031 & $33.68 \pm 0.33$ & $\mathrm{ab}$ & 0.849 & $34.29 \pm 0.30$ & $\mathrm{a}$ & 0.556 \\
\hline miR167a & $34.40 \pm 0.47$ & $\mathrm{~b}$ & 0.516 & $34.43 \pm 0.47$ & $\mathrm{~b}$ & 0.505 & $34.62 \pm 0.37$ & $\mathrm{ab}$ & 0.443 & $35.07 \pm 0.39$ & a & 0.324 \\
\hline \multicolumn{13}{|c|}{ Whole Blood } \\
\hline & & ont & & & NTI & & & $\mathrm{miI}$ & & No- & ate & trol \\
\hline & Cycle \# & & $\begin{array}{l}\text { Calculated } \\
\text { conc. (fM) }\end{array}$ & Cycle\# & & $\begin{array}{l}\text { Calculated } \\
\text { conc. (fM) }\end{array}$ & Cycle & & $\begin{array}{l}\text { Calculated } \\
\text { conc. (fM) }\end{array}$ & Сус & & $\begin{array}{l}\text { Calculated } \\
\text { conc. (fM) }\end{array}$ \\
\hline miR156a & $36.30 \pm 0.83$ & $\mathrm{a}$ & 0.138 & $36.66 \pm 0.78$ & $\mathrm{a}$ & 0.108 & $36.47 \pm 0.82$ & $\mathrm{a}$ & 0.123 & $36.89 \pm 1.85$ & $\mathrm{a}$ & 0.092 \\
\hline miR164a & $34.81 \pm 0.69$ & a & 0.388 & $34.81 \pm 0.63$ & a & 0.388 & $34.90 \pm 0.52$ & $\mathrm{a}$ & 0.365 & $34.90 \pm 0.20$ & a & 0.365 \\
\hline $\operatorname{miR} 167 a$ & $36.80 \pm 0.99$ & $\mathrm{a}$ & 0.098 & $36.86 \pm 0.46$ & a & 0.094 & $36.69 \pm 0.85$ & $\mathrm{a}$ & 0.105 & $37.26 \pm 1.00$ & a & 0.071 \\
\hline
\end{tabular}

* The concentrations were calculated with standard curves of respective miRNAs. Cycle numbers of RT-PCR were presented as Mean \pm SD $(n=10)$. Different letters indicate statistically significant differences $(p \leq 0.05)$. 


\subsection{Analysis of Corn miRNAs in Cecal and Fecal Samples}

Corn miRNA was also determined in cecal and fecal samples. In the corn sRNA study, no differences were detected in miRNA Ct values between the control, dNTP, and corn sRNA groups in the cecal or the fecal (from Days 2 and 14) samples. The Ct values of no-template controls for the cecal, fecal (from Days 2 and 14) were significantly higher than those of the experimental groups (Figure 2A). Cecal and fecal (Day 14) samples were then treated with periodate oxidation followed by $\beta$ elimination. After periodate treatment, no differences were detected between the no-template control group and the experimental groups in cecal samples. However, significant difference persisted in the fecal samples but the differences in $\mathrm{Ct}$ values were less (Figure 2A, Table 1).

A similar observation was made in the cecal and fecal (from Day 2 and 14) samples from the fresh corn powder study. Small but statistically significant differences were detected in miR167a Ct value in cecal and Day 2 fecal samples, and miR164a Ct value in Day 14 fecal samples. No-template control $\mathrm{Ct}$ values of cecal and fecal (from Days 2 and 14) samples were significantly higher than those of the experimental groups (Figure 2B). After periodate treatment, differences between the $\mathrm{Ct}$ values of the no-template control group and the experimental groups were much smaller compared to those before the periodate treatment in the cecal and the fecal samples (Figure 2B, Table 2).

Based on the standard curves constructed for each miRNA, the recovery rate of miRNAs from fecal samples were calculated according to the detection levels in qRT-PCR (Tables 3 and 4). Less than $0.1 \%$ of total miRNA (the sum of miR156a, miR164a, and miR167a) tested in both studies were recovered from the fecal samples.

Table 3. miRNAs recovered in fecal sample from study 1.

\begin{tabular}{cccc}
\hline miRNA & Intake from Gavage & Detected in Fecal Sample & \% Recovered \\
\hline miR156a & $56.03 \mathrm{pg}$ & $0.27 \mathrm{pg}$ & $0.48 \%$ \\
miR164a & $13.2 \mathrm{pg}$ & $0.25 \mathrm{pg}$ & $1.89 \%$ \\
miR167a & $1215.63 \mathrm{pg}$ & $0.39 \mathrm{pg}$ & $0.03 \%$ \\
\hline
\end{tabular}

Table 4. miRNAs recovered in fecal sample from study 2.

\begin{tabular}{cccc}
\hline miRNA & Intake from Diet & Detected in Fecal Sample & \% Recovered \\
\hline miR156a & $575.56 \mathrm{pg}$ & $0.31 \mathrm{pg}$ & $0.05 \%$ \\
miR164a & $217.36 \mathrm{pg}$ & $1.00 \mathrm{pg}$ & $0.46 \%$ \\
miR167a & $1716.44 \mathrm{pg}$ & $0.73 \mathrm{pg}$ & $0.04 \%$ \\
\hline
\end{tabular}

\subsection{Fate of Corn miRNA in Mouse GI Tract}

To assess the effect of digestion on the corn miRNA, corn miRNA was determined in the contents collected from different parts of mouse GI tract from our animal studies. Comparing to the amount of corn miRNA miR167a administered via gavage or food intake, the recovery of miRNAs in each section of the GI tract were calculated to account for less than $0.3 \%$ of originally ingested in the stomach, less than $0.1 \%$ of originally ingested in the intestine and feces, and less than $0.01 \%$ of originally ingested in colon and cecum (Figure 3).

\subsection{In Vitro Analyses of miRNA Recovery in GI Tract}

Given minimal corn miRNA was accounted for in samples collected, we used an in vitro digestion system to determine if degradation was responsible for the observations. Corn miRNAs supplemented in AIN-93M diet or miRNA extract, as well as methylated and unmethylated synthetic miR171j, were treated following an established in vitro digestion model [25]. After the oral phase, 53-66\% of the original corn miR167a were detected in the digestion fluid. Synthetic miR171j with or without $3^{\prime}$ end methylation was used as positive and negative controls and 33\% methylated miR171 $\mathrm{j}$ was recovered, 
while only $4 \%$ of the unmethylated miR171j were recovered after the oral phase (Figure 4 ). After the gastric phase, over $97 \%$ of corn miR167a in AIN diet or in the miRNA extract were degraded. Finally, after the intestinal phase, less than $1 \%$ of miR167a was detected in the samples (Figure 4).

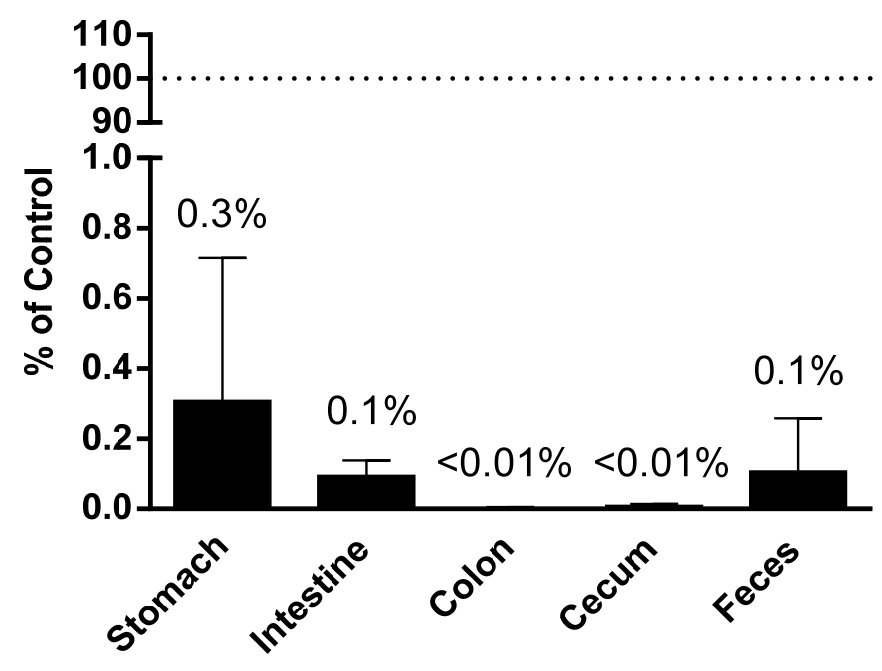

Figure 3. Plant miRNA detection in GI tract and in vitro digestion. Plant miRNA was extracted and quantified from contents of different sections of the GI tract. Recovery was calculated as the percentage of miR167a detected in each section of the GI tract comparing to the total amount detected in the consumed diet.

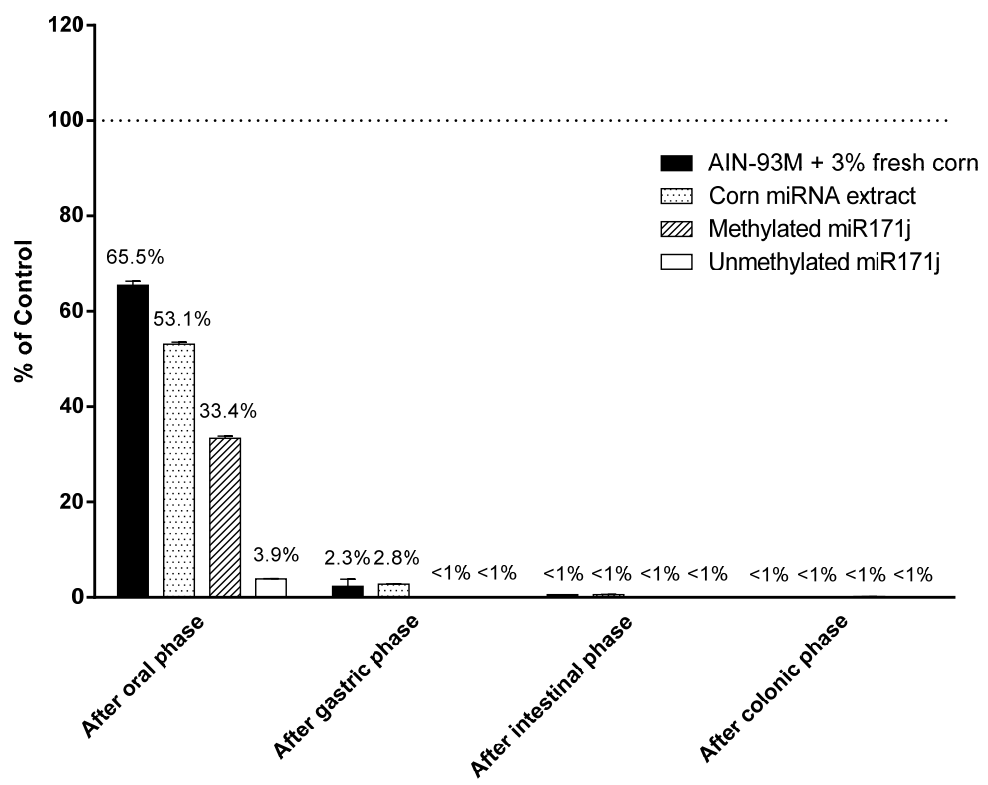

Figure 4. Plant miRNA detection after in vitro digestion. AIN-93M diet supplemented with $3 \%$ fresh corn powder, corn miRNA extract, or methylated or unmethylated miR171 $j$ were treated with in vitro digestion buffer as described in the Materials and Methods. Recovery was calculated as the percentage of miR167a or miR171j detected after each phase of digestion comparing to the amount measured in the starting materials. All treated samples are significantly different from the respective controls at $p<0.05$. 


\section{Discussion}

This study investigated the cross-kingdom transfer and bioavailability of plant miRNAs using corn miRNAs administrated in a mouse model and the presence or absence of the ingested miRNAs were analyzed in the diet, cecum, feces, liver, and in whole blood. An updated method using periodate oxidation reaction was employed to ensure the detected miRNA(s) in the biological samples are of plant origin. No detection of corn miRNAs was observed in the cecum, feces, liver, or in the blood following supplementation of corn miRNAs in the animal diet or gavage to the animals. In conjunction with our in vitro digestion study, we concluded that the corn miRNAs are extensively degraded during the digestive process and are not uptake into circulation or tissues in our mouse model.

Recent studies reported conflicting results in the detection of exogenous miRNAs in human or animal models [7-18]. Major issues appeared to be (1) the reliability of detection and (2) the biological significance of miRNA at the detected level. The reliability issue of detection may arise from false detection and authenticity of plant origin of the miRNAs. Oversampling in database analyses, potential contamination in sequencing study or false positive detection in PCR assay were pointed out as a possible mechanism of false detection in previous reports $[13,14,20]$. In this study, we tried to overcome the detection reliability issue by employing a detection method combining the sequence specificity (PCR) and characteristic structure of $3^{\prime}$ end methylation on the plant miRNAs (resistant to periodate oxidation). It is apparent from Figure 2 that potential false positive detections can occur in PCR-based assays, especially at high cycles ( $>30$ cycles). The differences were eliminated by periodate treatments that oxidize unmethylated miRNAs. It is possible that the confounding factor in cecal and fecal samples may be derived from mammalian miRNAs that are similar in sequences or immature plant miRNA that lack the $3^{\prime}$ methylation to protects miRNA from oxidation. A previous study by Luo et al. reported the detection of corn miRNAs in a pig model upon maize and chow consumption [26]. Similar levels of corn miRNAs in the fresh corn were reported by Luo and in this study (Supplementary Materials, Figure S1). Luo and colleagues treated the blood and tissue sample with periodate, which led to reductions in expression levels, while not completely eliminating the detection [26]. The discrepancy between the two studies may stem from the different periodate treatment methods used. Comparing the periodate treatment used in Luo's [26] studies, which was the same as that used by Zhang and colleagues in the 2012 study [6], periodate oxidation followed by alkaline $\beta$ elimination used in this study can degrade miRNAs without $3^{\prime}$ end methylation more efficiently [20]. The differences in the model animals and food intake may also contribute to the different results observed in the two studies.

A critical factor for dietary exogenous miRNAs to exert biologically significant effects is the amount of intact and functional miRNAs that actually reaches human or animal circulation and organs. In this study, no detectable levels of corn miRNAs were found in the circulation or the liver (Tables 1 and 2, Figure 2). In the GI tract, less than $0.1 \%$ of corn miRNAs were accounted for and in vitro analysis showed that the dietary miRNAs were quickly and almost completely digested before arriving in the small intestine (Figure 4). Upon losing the intact sequence and the $3^{\prime}$ end methylation, the corn miRNAs may undergo further degradation in the GI tract to individual nucleotides. These nucleotides may be used by gut bacteria or taken up during absorption. However, the amounts of free nucleotides from miRNAs account for a small fraction of the total nucleotides ingested from a dietary source, e.g., genomic DNA and RNA in the food, and is therefore not expected to play an important role as free nucleotides. Therefore, at least for miRNA derived from corn, they are not likely to be available for systemic absorption. Previous studies reported that food matrix, such as exosome packaging of bovine milk miRNAs, can improve the stability of the miRNAs against digestion $[27,28]$. However, no differences were observed in this study between corn miRNA extract or fresh corn powder supplements. Conflicting evidence of whether certain genetic materials can survive the GI tract was reported in previous studies [29]. Using a different in vitro digestion model consisting of a simulated gastric phase, Philip and colleagues reported that when subjecting soybean seeds to up to $75 \mathrm{~min}$ in vitro digestion, soy miRNAs can be detected from the digestion fluid [29]. In this study, a substantial amount of the corn miRNA was degraded in the oral phase, which was missing in Philip's 
study. The $\alpha$-amylase used in this study was prepared from crude human saliva, and therefore, may contain additional enzymes or substances in trace amounts to break down miRNAs. Such reactions may mimic the actual conditions in the oral phase. The extent of degradation in the oral phase may be affected by a number of factors, such as the protective effect of the matrix (AIN-93M diet vs. miRNA extract), the type and amounts of miRNAs (corn miRNAs vs. miR171j), and the methylation status. In other studies, plant miRNAs were observed to be significantly or completely degraded in the GI tract $[13,15,17,18]$. Considering the absence of detectable corn miRNAs in the circulation and liver in this study and the minimal recovery in the GI tract, the significance and biological relevance of exogenous miRNA transfer may be limited to selected plant foods.

\section{Conclusions}

Significant degradation of corn miRNAs occurred during digestion which resulted in minimal uptake of corn miRNAs after oral consumption. No corn miRNAs could be detected in whole blood, cecal or liver of the animals. Moreover, degradation of corn miRNAs in the GI tract occurred relatively early and therefore cross-kingdom transfer of exogenous miRNAs appears to be insignificant and not biologically relevant.

Supplementary Materials: The following are available online at www.mdpi.com/2072-6643/10/2/215/s1, Figure S1: Stability of corn miRNAs in the AIN-93M diet at the start and end of the feeding period, Figure S2: Degradation of corn miRNAs after autoclaving, Table S1: Diet composition.

Acknowledgments: This study was supported by U.S. Department of Agriculture appropriated fund \#8040-51530-056-00D and Office of Dietary Supplements Interagency Reimbursable Agreement \#8040-51530-056-20-I.

Author Contributions: H.H., C.D.D. and T.T.Y.W. conceived and designed the experiments; H.H. performed the experiments; H.H. analyzed the data; H.H. wrote the paper; H.H., C.D.D. and T.T.Y.W. reviewed and revised the paper.

Conflicts of Interest: The authors declare no conflict of interest.

\section{References}

1. Bartel, D.P. MicroRNAs: Genomics, biogenesis, mechanism, and function. Cell 2004, 116, 281-297. [CrossRef]

2. He, L.; Hannon, G.J. MicroRNAs: Small RNAs with a big role in gene regulation. Nat. Rev. Genet. 2004, 5, 522-531. [CrossRef] [PubMed]

3. Baer, C.; Claus, R.; Plass, C. Genome-wide epigenetic regulation of mirnas in cancer. Cancer Res. 2013, 73, 473-477. [CrossRef] [PubMed]

4. Satoh, J. Molecular network analysis of human microRNA targetome: From cancers to Alzheimer's disease. Biodata Min. 2012, 5, 22. [CrossRef] [PubMed]

5. Ranjha, R.; Paul, J. Micro-RNAs in inflammatory diseases and as a link between inflammation and cancer. Inflamm. Res. 2013, 62, 343-355. [CrossRef] [PubMed]

6. Zhang, L.; Hou, D.X.; Chen, X.; Li, D.H.; Zhu, L.Y.; Zhang, Y.J.; Li, J.; Bian, Z.; Liang, X.Y.; Cai, X.; et al. Exogenous plant MIR168a specifically targets mammalian LDLRAP1: Evidence of cross-kingdom regulation by microRNA. Cell Res. 2012, 22, 107-126. [CrossRef] [PubMed]

7. Zhang, Y.J.; Wiggins, B.E.; Lawrence, C.; Petrick, J.; Ivashuta, S.; Heck, G. Analysis of plant-derived miRNAs in animal small RNA datasets. BMC Genomics 2012, 13. [CrossRef] [PubMed]

8. Wang, K.; Li, H.; Yuan, Y.; Etheridge, A.; Zhou, Y.; Huang, D.; Wilmes, P.; Galas, D. The complex exogenous RNA spectra in human plasma: An interface with human gut biota? PLoS ONE 2012, 7, 13. [CrossRef] [PubMed]

9. Beatty, M.; Guduric-Fuchs, J.; Brown, E.; Bridgett, S.; Chakravarthy, U.; Hogg, R.E.; Simpson, D.A. Small RNAs from plants, bacteria and fungi within the order hypocreales are ubiquitous in human plasma. BMC Genomics 2014, 15, 933. [CrossRef] [PubMed]

10. Yang, J.; Farmer, L.M.; Agyekum, A.A.; Elbaz-Younes, I.; Hirschi, K.D. Detection of an abundant plant-based small RNA in healthy consumers. PLoS ONE 2015, 10, e0137516. [CrossRef] [PubMed] 
11. Chin, A.R.; Fong, M.Y.; Somlo, G.; Wu, J.; Swiderski, P.; Wu, X.; Wang, S.E. Cross-kingdom inhibition of breast cancer growth by plant MIR159. Cell Res. 2016, 26, 217-228. [CrossRef] [PubMed]

12. Lukasik, A.; Zielenkiewicz, P. In silico identification of plant miRNAs in mammalian breast milk exosomes-a small step forward? PLoS ONE 2014, 9, e99963. [CrossRef] [PubMed]

13. Snow, J.W.; Hale, A.E.; Isaacs, S.K.; Baggish, A.L.; Chan, S.Y. Ineffective delivery of diet-derived microRNAs to recipient animal organisms. RNA Biol. 2013, 10, 1107-1116. [CrossRef] [PubMed]

14. Witwer, K.W.; McAlexander, M.A.; Queen, S.E.; Adams, R.J. Real-time quantitative PCR and droplet digital PCR for plant miRNAs in mammalian blood provide little evidence for general uptake of dietary mirnas limited evidence for general uptake of dietary plant xenomirs. RNA Biol. 2013, 10, 1080-1086. [CrossRef] [PubMed]

15. Dickinson, B.; Zhang, Y.J.; Petrick, J.S.; Heck, G.; Ivashuta, S.; Marshall, W.S. Lack of detectable oral bioavailability of plant microRNAs after feeding in mice. Nat. Biotechnol. 2013, 31, 965-967. [CrossRef] [PubMed]

16. Witwer, K.W. Contamination or artifacts may explain reports of plant miRNAs in humans. J. Nutr. Biochem. 2015, 26, 1685. [CrossRef] [PubMed]

17. Yang, J.; Primo, C.; Elbaz-Younes, I.; Hirschi, K.D. Bioavailability of transgenic microRNAs in genetically modified plants. Genes Nutr. 2017, 12, 17. [CrossRef]

18. Micó, V.; Martín, R.; Lasunción, M.A.; Ordovás, J.M.; Daimiel, L. Unsuccessful detection of plant microRNAs in beer, extra virgin olive oil and human plasma after an acute ingestion of extra virgin olive oil. Plant Foods Hum. Nutr. 2016, 71, 102-108. [CrossRef] [PubMed]

19. Yu, B.; Yang, Z.; Li, J.; Minakhina, S.; Yang, M.; Padgett, R.W.; Steward, R.; Chen, X. Methylation as a crucial step in plant microRNA biogenesis. Science 2005, 307, 932-935. [CrossRef] [PubMed]

20. Huang, H.; Roh, J.; Davis, C.D.; Wang, T.T. An improved method to quantitate mature plant microRNA in biological matrices using modified periodate treatment and inclusion of internal controls. PLoS ONE 2017, 12, e0175429. [CrossRef] [PubMed]

21. Zhang, L.; Chia, J.-M.; Kumari, S.; Stein, J.C.; Liu, Z.; Narechania, A.; Maher, C.A.; Guill, K.; McMullen, M.D.; Ware, D. A genome-wide characterization of microRNA genes in maize. PLoS Genet. 2009, 5, e1000716. [CrossRef] [PubMed]

22. Ray, D.K.; Mueller, N.D.; West, P.C.; Foley, J.A. Yield trends are insufficient to double global crop production by 2050. PLoS ONE 2013, 8, e66428. [CrossRef] [PubMed]

23. Ranum, P.; Peña-Rosas, J.P.; Garcia-Casal, M.N. Global maize production, utilization, and consumption. Ann. N. Y. Acad. Sci. 2014, 1312, 105-112. [CrossRef] [PubMed]

24. Rosas-Cardenas, F.D.; Duran-Figueroa, N.; Vielle-Calzada, J.P.; Cruz-Hernandez, A.; Marsch-Martinez, N.; de Folter, S. A simple and efficient method for isolating small RNAs from different plant species. Plant Methods 2011, 7. [CrossRef] [PubMed]

25. Minekus, M.; Alminger, M.; Alvito, P.; Ballance, S.; Bohn, T.; Bourlieu, C.; Carriere, F.; Boutrou, R.; Corredig, M.; Dupont, D. A standardised static in vitro digestion method suitable for food-An international consensus. Food Funct. 2014, 5, 1113-1124. [CrossRef] [PubMed]

26. Luo, Y.; Wang, P.; Wang, X.; Wang, Y.; Mu, Z.; Li, Q.; Fu, Y.; Xiao, J.; Li, G.; Ma, Y. Detection of dietetically absorbed maize-derived microRNAs in pigs. Sci. Rep. 2017, 7, 645. [CrossRef] [PubMed]

27. Izumi, H.; Kosaka, N.; Shimizu, T.; Sekine, K.; Ochiya, T.; Takase, M. Bovine milk contains microRNA and messenger RNA that are stable under degradative conditions. J. Dairy Sci. 2012, 95, 4831-4841. [CrossRef] [PubMed]

28. Ge, Q.; Zhou, Y.; Lu, J.; Bai, Y.; Xie, X.; Lu, Z. MiRNA in plasma exosome is stable under different storage conditions. Molecules 2014, 19, 1568-1575. [CrossRef] [PubMed]

29. Philip, A.; Ferro, V.A.; Tate, R.J. Determination of the potential bioavailability of plant microRNAs using a simulated human digestion process. Mol. Nutr. Food Res. 2015, 59, 1962-1972. [CrossRef] [PubMed]

(C) 2018 by the authors. Licensee MDPI, Basel, Switzerland. This article is an open access article distributed under the terms and conditions of the Creative Commons Attribution (CC BY) license (http:/ / creativecommons.org/licenses/by/4.0/). 